\title{
Phytochemical Constituents, Total Saponins, Alkaloids, Flavonoids and Vitamin C Contents of Ethanol Extracts of five Solanum torvum Fruits
}

\author{
Desmond Ato Koomson' ${ }^{1}$ Benjamin Danso Kwakye ${ }^{2}$, Williams Kweku Darkwah ${ }^{1,3 *}$, Bismark Odum ${ }^{4}$, \\ Mabel Asante ${ }^{5}$, Gideon Aidoo ${ }^{6}$
}

\section{Desmond Ato Koomson', Benjamin Danso Kwakye², Williams Kweku Dark- wah $^{1,3 *}$, Bismark Odum ${ }^{3,4}$, Mabel Asante ${ }^{5}$, Gideon Aidoo $^{6}$}

'Department of Biochemistry, School of Biological Sciences, University of Cape Coast, Cape Coast, GHANA

2Department of Mathematics, College of Science, Hohai University, Nanjing, CHINA.

${ }^{3}$ Key Laboratory of Integrated Regulation and Resource Development on Shallow Lakes, Ministry of Education, Environmental Engineering Department, College of Environment, Hohai University, Nanjing, CHINA.

${ }^{4}$ Chemical Engineering Department, College of Engineering, Kwame Nkrumah University of Science and Technology, Kumasi, GHANA. ${ }^{5}$ Department of Laboratory Technology, School of Physical Sciences, University of Cape Coast, Cape Coast, GHANA.

${ }^{6}$ Clinical Research Laboratory Department,

37-Military Teaching Hospital, Accra, GHANA.

Correspondence

Williams Kweku Darkwah

Key Laboratory of Integrated Regulation and Resource Development on Shallow Lakes, Ministry of Education,

Environmental Engineering Department, College of Environment, Hohai University, Nanjing, CHINA

Phone no : +86152957 82807

E-mail: williams.darkwah@stu.ucc.edu.gh

History

- Submission Date: 03-04-2018;

- Review completed: 28-06-2018

- Accepted Date: 18-07-2018

DOI : 10.5530/pj.2018.5.160

Article Available online

http://www.phcogj.com/v10/i5

Copyright

(c) 2018 Phcog.Net. This is an openaccess article distributed under the terms of the Creative Commons Attribution 4.0 International license.

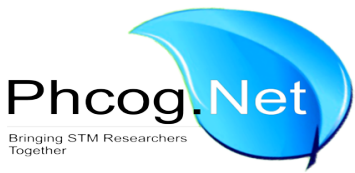

\section{ABSTRACT}

Introduction: Phytochemicals are frequently used in chemotherapeutic treatment or may be used as chemo preventive agents with chemoprevention. The study report the quantification of phytochemical constituents and vitamin C contents from ethanol extracts of Solanum torvum fruits. Method:The main objective for this research was to use standard procedures to determine phytochemical and vitamin C content. Results: The estimated alkaloids found in mature fruits were $6.32 \pm 0.12 \mathrm{mg} / \mathrm{g}$ and $16.94 \pm 2.3 \mathrm{mg} / \mathrm{g}$ in the immature fruits. Total saponins in mature and immature fruits were $8.60 \pm 2.6 \mathrm{mg} / \mathrm{g}$ and $16.90 \pm 9.4 \mathrm{mg} / \mathrm{g}$ respectively. Total flavonoids in mature and immature fruits were $21.14 \pm 4.4 \mathrm{mg} / \mathrm{g}$ and $14.24 \pm 1.8 \mathrm{mg} / \mathrm{g}$ respectively. Also vitamin $C$ contents were $11.79 \pm 2.0 \mathrm{mg} / \mathrm{g}$ in mature fruits and $8.70 \pm 0.26 \mathrm{mg} / \mathrm{g}$ in immature fruits. With the exception of alkaloids whose difference in the mature and immature was significant, other differences obtained were not significant. Conclusion: The study showed that the extracts contain diversity of phytochemicals in appreciable amount that can expertly keep the body against oxidative stress triggered by free radicals and therefore be used as a source of potent natural products.

Key words: Solanum torvum fruits, Phytochemicals, Saponins, Flavonoids, Alkaloids, Ethanol extract.

\section{INTRODUCTION}

Scientists have suggested that phytochemicals posse different kinds of mechanisms of action. These compounds are known to obstruct microorganisms, and also impede some metabolic routes or control gene expression and signal transduction pathways. ${ }^{1-2}$ Phytochemicals such as alkaloids, phenols, saponins are frequently used in chemotherapeutic treatment or may be used as chemo preventive agents with chemoprevention referring to the use of agents to constrain, reverse, or delay tumorigenesis. With this logic, chemo preventive phytochemicals are pertinent to cancer treatment, since molecular mechanisms may be common to chemoprevention and cancer healing. ${ }^{3-4}$

Phytochemicals, for instance, alkaloids, saponins, flavonoids and phenolic compounds also play an important role in the growth and reproduction of most plants, these compounds also act as antifeedants and antipathogens. ${ }^{5}$ These compounds also turn as a natural protective mechanism by hindering mutations in plants.
Solanum torvum fruits are very rich in vitamin C. In spite of being rich in vitamin $\mathrm{C}$, they also provide phytochemicals such as alkaloids, saponins, sugars, phenols and flavonoids folate, potassium and a lot of fiber for pharmaceutical or food production. Solanum torvum is a rich source of alkaloids, flavonoids, saponins, glycosides, and tannins. ${ }^{7}$ According to Pérez-Amador, ${ }^{8}$ the percentage constituents of various phytochemical compounds within this fruit is highly appreciable. Regardless of broad research on the medicinal properties of most plants, little information is known about the many humid underutilized plants and fruits in most unindustrialized countries specifically Ghana. One of such fruit is Solanum torvum which is a multipurpose constant slender herb. Consequently, in this research, quantification of phytochemical constituents and vitamin C contents by ethanol extracts of Solanum torvum fruits were investigated to evaluate the potential protective or health benefits of this fruits and their linkage to their medicinal properties.
Cite this article: Koomson DA, Kwakye BD, Darkwah WK, Odum B, Asamoah KA, Aidoo G. Phytochemical Constituents, Total Saponins, Alkaloids, Flavonoids and Vitamin C Contents of Ethanol Extracts of five Solanum torvum Fruits. Pharmacog J. 2018;10(5):946-50. 


\section{MATERIALS AND METHODS}

\section{Determination of people's knowledge on Solanum torvum using questionnaires}

A survey was done with the households at Kotokoraba near University of Cape Coast, Cape Coast, Ghana. This was done using questionnaires to help know people's knowledge on S. torvum. The data was collected and analyzed using SPSS analysis.

\section{Plant Material}

Five fresh fruits Solanum torvum were collected from the University of Cape Coast botanical garden, Cape Coast, Ghana with voucher numbers UCCBG000445, UCCBG000448, UCCBG000349, UCCBG000387 and UCCBG000543. The taxonomic character of the fruits was determined on $2^{\text {nd }}$ December, 2014 by a plant taxonomist at the Department of Botany, University of Cape Coast, Ghana. Solanum torvum fruits were then washed under with water to get rid of undesirable dirt and other external constituents. The samples were parched under shade until no moisture left. The parched samples then were ground into powder using a blender.

\section{Ethanol extraction}

The ethanol extract from Solanum torvum fruits was also prepared by drenching $50 \mathrm{~g}$ of the grinded sample in $500 \mathrm{~mL}$ of sterilized distilled water for $2 \mathrm{~h}$ in $90^{\circ} \mathrm{C}$ water bath at the Department of Biochemistry Research Laboratory, University of Cape Coast, Ghana. The combination was then filtered using Whatman filter paper No 1. The filtrate was concentrated under a reduced pressure using a rotary evaporator at a temperature of $90^{\circ} \mathrm{C}$. The resulting extract was weighed and put in storage in impermeable bottles at $35^{\circ} \mathrm{C}$ for further analysis.

$$
\text { yidis }(\infty)-\left(\frac{A_{1}}{A_{0}}\right) \times 100
$$

Where, $A_{0}$ was the mass of the sample and $A_{1}$ was the mass of the crude extract.

\section{Phytochemical screening Qualitative analysis}

Phytochemical qualitative test of the ethanol extracts of Solanum torvum was performed as per standard protocols ${ }^{9-12}$ to reveal the existence of glycosides, tannins, flavonoids, saponins, alkaloids anthraquinones.

\section{Quantitative Analysis \\ Determination of total saponins}

The 10 samples were ground and $2 \mathrm{~g}$ of each was put into a conical flask and $10 \mathrm{ml}$ of $20 \%$ aqueous ethanol was added. The samples were heated over a hot water bath for $4 \mathrm{~h}$ with continuous stirring at about $55^{\circ} \mathrm{C}$. The mixture was filtered and the residue re-extracted with another $20 \mathrm{ml}$ of $20 \%$ ethanol. The combined extracts were concentrated over water bath at about $90^{\circ} \mathrm{C}$. The concentrate was transferred into a $250 \mathrm{ml}$ separating funnel and $10 \mathrm{ml}$ of diethyl ether was added and shaken strongly. The aqueous layer was recovered while the ether layer was cast-off. The purification process was repeated. $6 \mathrm{ml}$ of n-butanol was added. The combined n-butanol extracts were washed twice with $1 \mathrm{ml}$ of $5 \%$ aqueous sodium chloride. The residual solution was heated in a water bath. After evaporation the samples were dried in the oven to a constant weight; the saponin content was calculated. ${ }^{13}$

\section{Determination of total alkaloids}

Exactly $1 \mathrm{~g}$ of the sample was weighed into a $250 \mathrm{ml}$ beaker and $40 \mathrm{ml}$ of $10 \%$ acetic acid in ethanol was added and covered and allowed to stand for $4 \mathrm{~h}$. This was filtered and the extract was concentrated on a water bath to one-quarter of the original volume. Concentrated ammonium hydroxide was added drop wise to the extract until the precipitation was complete. The whole solution was allowed to settle and the precipitate was collected and washed with dilute ammonium hydroxide and then filtered. The residue is the alkaloid, which was dried and weighed. ${ }^{14}$

\section{Determination of total flavonoids}

Exactly $1 \mathrm{~g}$ of the plant sample was extracted repeatedly with $10 \mathrm{ml}$ of $80 \%$ aqueous methanol at room temperature. The whole solution was filtered through whatman filter paper No $42(125 \mathrm{~mm})$. The filtrate was later transported into a container and evaporated into dryness over a water bath and weighed to a constant weight. ${ }^{15}$

\section{Determination of Vitamin C}

About $3.5 \mathrm{~g}$ of the cleaned fresh 10 samples was measured. The samples were ground with a clean mortar and pestle which had been rinsed with oxalic acid. Exactly $50 \mathrm{ml}$ of oxalic acid was used in each case to grind and dissolve each sample. The mixtures were filtered using cotton wool and collected in separate labeled beakers. After that, $10 \mathrm{ml}$ of each filtrate was pipetted into a conical flask and $1 \mathrm{ml}$ of bromine water was added with constant mixing until the colour of the solution had changed to orange yellow. This was to remove phenolic hydrogen atoms in the ascorbic acid. Thiourea was added to the solutions in drops to expel off excess bromine. The volume of each of these sample solutions was made up to $50 \mathrm{ml}$ by the addition of $4 \%$ oxalic acid solution. The same procedure was followed for $10 \mathrm{ml}$ of stock ascorbic acid solution which has been prepared earlier to convert it to dehydroascorbic acid by bromination, followed by expelling excess with $10 \%$ thiourea. $0.05 \mathrm{ml}, 0.10 \mathrm{ml}, 0.15 \mathrm{ml}, 0.20 \mathrm{ml}, 0.25 \mathrm{ml}$, $0.30 \mathrm{ml}, 0.35 \mathrm{ml}, 0.40 \mathrm{ml}, 0.45 \mathrm{ml}$ and $0.5 \mathrm{ml}$ of the dehydroascorbic acid were pipette out into a series of test tubes. Similarly $1 \mathrm{ml}$ of each of the brominated samples were pipetted out into a series of tubes and their volumes made up to $3 \mathrm{ml}$ by adding distilled water. To each of the tubes was added $1 \mathrm{ml}$ of 2, 4-dinitrophenylhydrazine (2, 4-DNPH) followed by 2 drops of thiourea. A blank (containing $3 \mathrm{ml}$ of distilled water, $1 \mathrm{ml}$ of 2 , 4 -DNPH, and drops of thiourea) was prepared. The contents were mixed thoroughly and then put in the water bath, at $40^{\circ} \mathrm{C}$ for $3 \mathrm{~h}$. After $3 \mathrm{~h}$ of incubation, $6 \mathrm{ml}$ of $80 \%$ sulphuric acid was added to each solution and allowed to cool slowly in free air. Absorbance of the blank, the samples, and the standards were measured at $540 \mathrm{~nm}$ and tabulated. A standard curve was plotted and from it, the various concentrations of vitamin $\mathrm{c}$ in the samples were calculated. This was triplicated. ${ }^{16}$

\section{RESULTS AND DISCUSSION}

\section{RESULTS}

\section{Survey}

The survey revealed the knowledge of the local people about the fruits of S. torvum. From the survey, the plant is widely known among the local 
people (Figure 1). It has been assigned various names such as Beware, Kwau Nsusuwa, Samantroba, Ananantroba, etc.

\section{Qualitative determination of the phytochemical constituents of ethanol extract of Solanum torvum}

Solanum torvum has been largely considered, precisely its medicinal possessions correlated with stable phytochemicals. ${ }^{17}$ Several parts of Solanum torvum have been in use for the separation of an extensive collection of compounds. This plant kind is a precise good source of phytochemical components. ${ }^{7}$ Phytochemical study of the ethanol extract of $S$. torvum revealed the presence of glycosides, tannins, flavonoids, saponins, alkaloids but no anthraquinones (Table 1).

\section{Quantitative determination of total alkaloid, saponin and flavonoid Contents of ethanol extract of Solanum torvum fruits}

There were different compositions of phytochemicals in the fruit samples of $S$. torvum. There were no significant differences statistically in the levels of flavonoids, and saponins between the mature and young fruits of the S. torvum (Table 2; Figure 2-4). There was a statistically significant difference in the levels of alkaloids between the matured and young fruits of the S. torvum (Table 2; Figure 2-4).

\section{Quantitative analysis of vitamin C content of ethanol extract of Solanum torvum fruits}

From the experiment there was no statistical significant difference in the levels of vitamin $\mathrm{C}$ contents between the matured and young fruits of the S. torvum (Figure 5)

\section{DISCUSSIONS}

Most of the people surveyed used the fruits for food, tea or medicine (Figure 1). There has also been a report of the use of the fruits as food in most Asian countries. ${ }^{18}$ The advantages in using the fruits for food were well known to the people surveyed. The fruits have been used by the people from about 2 years to 40 years. This gave the basis to experimentally determine the nutritional or medicinal value of the fruits, especially the phytochemicals and vitamin $\mathrm{C}$ constituents.

Sivapriya and Srinivas ${ }^{19}$ and Lakshmi ${ }^{20}$ described phytochemical screening of methanolic and ethanol extracts of sun dried S. torvum fruits having the same results as this study had. The presence of these bioactive composites in the extract point out the prospective health remunerations of the plant. The existence of flavonoids and other phytochemical compounds improves the prospect of antioxidant activity, as many studies have informed a robust progressive correlation between these compounds and the antioxidant activity of extracts. ${ }^{12,21-23}$

Young fruits normally store phytochemicals such as alkaloids to protect them from infections and insects. The alkaloids begin to reduce and their concentrations weaken as the fruits mature and ripen. Environmental influences such as soil type, growing season, geographic location, and mineral status are known to impact intensities of plant secondary metabolites. ${ }^{24} S$. torvum fruits that exhibited great altitudes of phytochemicals may be strong to insects and diseases using the phytochemicals as protective chemicals ${ }^{25-28}$ in recent times demonstrated that anti-oxidant possessions of flavonoids and their ability to chelate free metallic ions could be operational in reducing the poisonousness of Doxorubicin (DOX) 39. The presence of flavonoids in S. torvum makes the fruit a very potent antioxidant.

The altitudes of vitamin $\mathrm{C}$ in vegetables and fruits differ subjected on some factors such as maturity state, position of the fruit on the branch

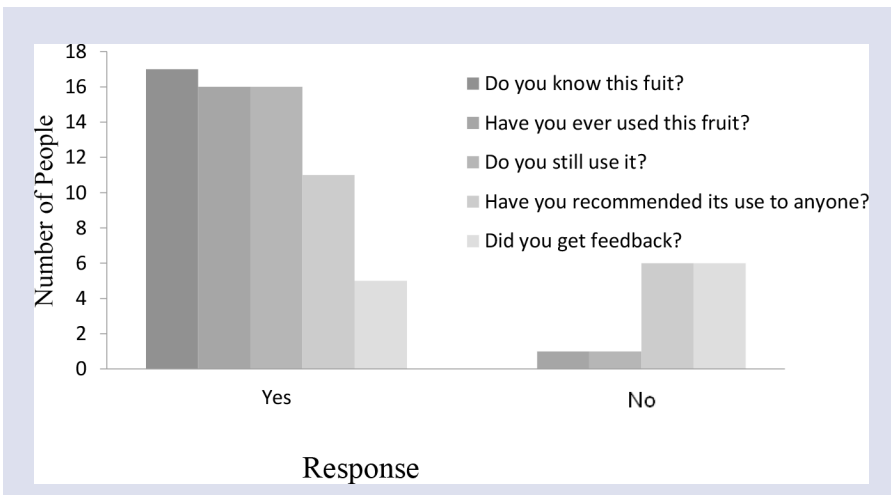

Figure 1: Knowledge of people on Solanum torvum.

Table 1: Phytochemicals present in the fruit of Solanum torvum.

\begin{tabular}{ccc}
\hline Phytochemicals & Young Fruit & Mature Fruit \\
\hline Glycosides & Present & Present \\
Tannins & Present & Present \\
Flavonoids & Present & Present \\
Saponins & Present & Present \\
Anthraquinones & Absent & Absent \\
Alkaloids & Present & Present \\
\hline
\end{tabular}

Table 2: Quantitative contents of phytochemicals in Solanum torvum (mg/g).

\begin{tabular}{ccccccc}
\hline \multirow{2}{*}{ Samples } & \multicolumn{2}{c}{ Flavonoids } & \multicolumn{2}{c}{ Saponins } & \multicolumn{2}{c}{ Alkaloids } \\
& Y & M & Y & M & Y & M \\
\hline 1 & 14.3 & 22.2 & 5.5 & 9.5 & 6.7 & 5.9 \\
2 & 18.7 & 13.1 & 14.5 & 2.5 & 16.0 & 6.4 \\
3 & 7.8 & 32.1 & 8.5 & 9.5 & 16.0 & 6.6 \\
4 & 15.9 & 9.2 & 53.5 & 17.5 & 14.9 & 6.3 \\
5 & 14.5 & 29.1 & 2.5 & 4.0 & 21.1 & 6.4 \\
\hline
\end{tabular}

"M" Matured fruits

"Y" Young fruits

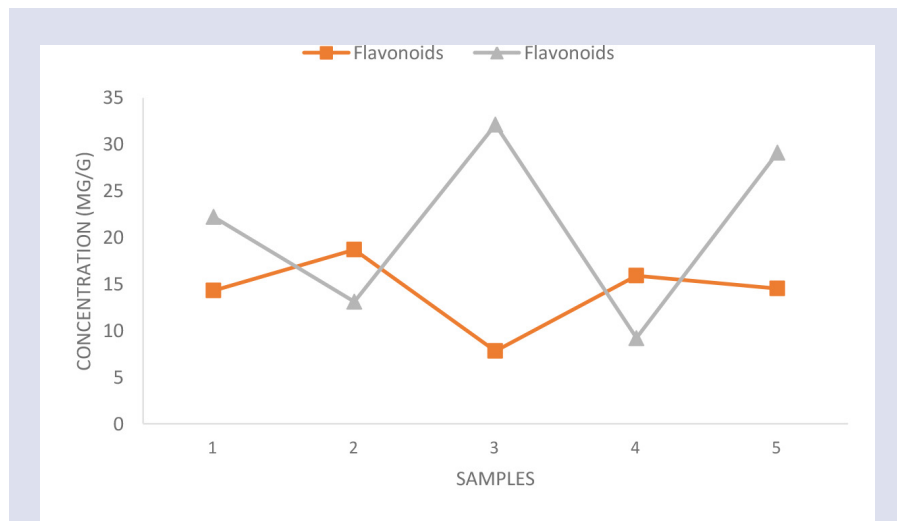

Figure 2: Total flavonoid contents of Solanum torvum (mg/g). 


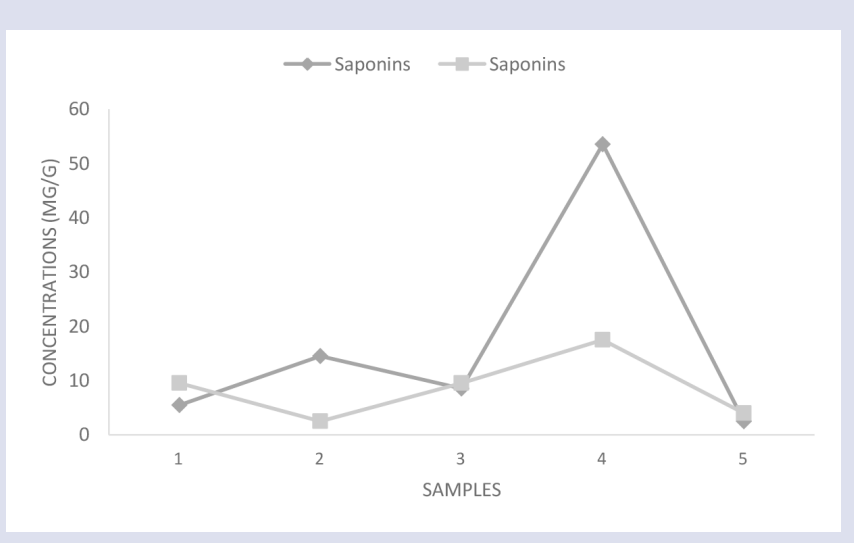

Figure 3: Saponin contents of Solanum torvum $(\mathrm{mg} / \mathrm{g})$.

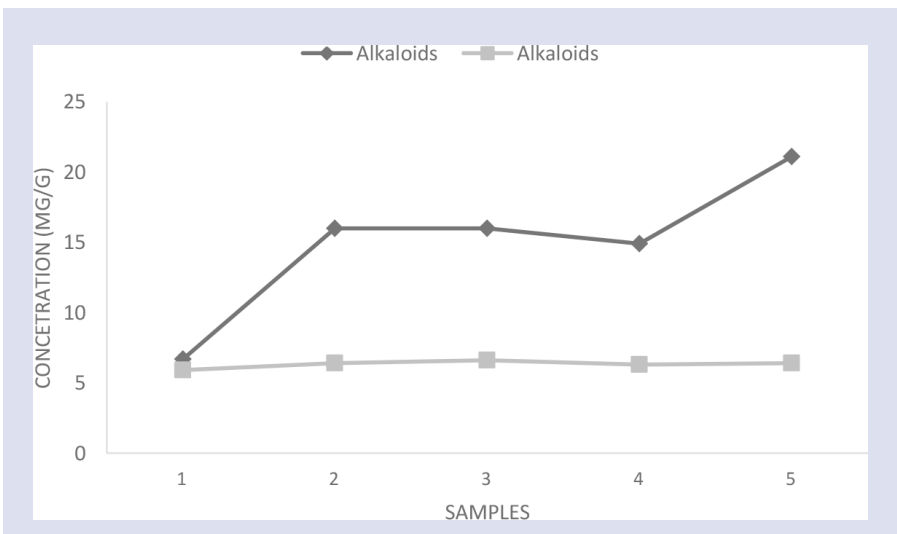

Figure 4: Total Alkaloid contents of Solanum torvum (mg/g).

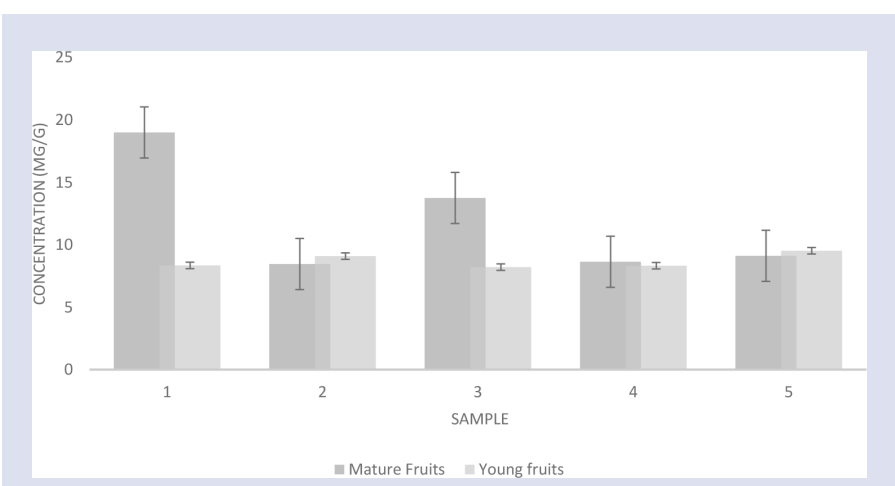

Figure 5: Concentrations of Vitamin C in fruit samples of Solanum torvum.

of the stem, temperature, storage, processing, varieties and handling. ${ }^{29}$ To compare to this study, vitamin $\mathrm{C}$ decreases throughout the ripening process. Immature fruit has the highest levels according to previous studies but with this study, matured fruits had the highest content of vitamin C
(Figure 5). Vitamin $\mathrm{C}$ is the most important water-soluble antioxidant found in the body. ${ }^{30-32}$ It lowers blood pressure and cholesterol levels. ${ }^{33}$ The presence of vitamin $\mathrm{C}$ in the fruits of $S$. torvum will help decline the possibility of heart related diseases.

\section{CONCLUSION}

The outcomes of the study point out that extracts of Solanum torvum fruits comprise of diversity of phytochemical compounds that can expertly protect the body against oxidative stress caused by free radicals and as a result might be used as a source of potent natural food or medicinal compounds. The vitamin C content of Solanum torvum could substantiate additional analysis of its other constructive natural properties and regulate its protection.

\section{ACKNOWLEDGEMENT}

The authors are grateful to the College of International Education, Hohai University, Nanjing, China and Biochemistry Research Laboratory, Department of Biochemistry, School of Biological Sciences, University of Cape Coast, Cape Coast, Ghana for their support. Williams Kweku Darkwah, Bismark Odum and Benjamin Danso Kwakye were the recipients of a scholarship from the China Scholarship Council (CSC) and Hohai University respectively for the duration of this work.

\section{CONFLICT OF INTEREST}

The Authors declare that they have no conflict of interest.

\section{ABBREVIATIONS}

CSC: China Scholarship Council; M: Matured fruits; Y: Young fruit; DOX: Doxorubicin; 2, 4-DNPH: 2, 4-dinitrophenylhydrazine; $\mathbf{A}_{0}$ : Mass of the sample; $\mathbf{A}_{1}$ : Mass of the crude extract.

\section{REFERENCES}

1. Kris-Etherton PM, et al. Bioactive compounds in foods: their role in: the prevention of 14. Cardiovascular disease and cancer. American Journal of Medicine. 2002;113(9):71-88.

2. Surh YJ. Cancer chemoprevention with dietary phytochemicals. Natural Reviews Cancer. 2003;3(10):768.

3. D'Incalci M, Steward WP, Gescher AJ. Use of cancer chemopreventive Phytochemicals as antineoplastic agents. Lancet Oncology. 2005;6(11):899-904.

4. Sarker SD, Nahar L. Chemistry for Pharmacy Students General, Organic and Natural Product Chemistry. England: John Wiley and Sons. 2007;283-359.

5. Butler LG. Anti-nutritional effects of condensed and hydrolysable tannins. Cancer. 1992;3:768-80.

6. Amjad M, lqbal I, Rees D, lqbal Q, Nawaz A, Ahmed T. Effect of Packing Materials and Different Storage Regimes on Shelf Life of Green Hot Pepper Fruits. Acta Horticulturae Journal. 2010;8:227-34.

7. Chah KF, Muko KN, Oboegbulem SI. Antimicrobial activity of methanolic extract of Solanum torvum fruit. Fitoterapia. 2000;71(2):187-9.

8. Pérez-Amadorl MC, Muñoz OV, García JM, Castañeda1 AR, González E. Alkaloids in Solanum torvum Sw (Solanaceae). International experimental Botany. 2007;76:39-45.

9. Harborne A. Phytochemical methods a guide to modern techniques of plant analysis, Springer Science and Business Media.

10. Trease G, Evans W. A text book of pharmacognosy Academic press. London. 1989;198:22-40

11. Meda A, Lamien CE, Romito M, Millogo J, Nacoulma OG. Determination of the total phenolic, Flavonoid and proline contents in Burkina Fasan honey, as well as their radical scavenging activity. Food Chemistry. 2005;91(3):571-7.

12. Darkwah WK, Ao Y, Adinortey MB, Weremfo A, Abrokwah FK, Afriyie E. Total Phenolic, Flavonoid and Alkaloid Contents, Oxidative DNA Damage Protective and Antioxidant Properties of Methanol and Aqueous Extracts of Dissotis rotundifolia Whole Plant. Free Radicals and Antioxidants. 2018;8(2).

13. Obdoni BO, Ochuko PO. Phytochemical studies and comparative efficacy of the crude extracts of some Homostatic plants in Edo and Delta States of Nigeria. Global J Pure Appl Sci. 2001;8(2):203-8.

14. Harborne JB. Phytochemical methods. London. Chapman and Hall, Ltd. 1973;49-188. 
15. Boham BA, Kocipai-Abyazan R. Flavonoids and condensed tannins from leaves of Hawaiian Vaccinium vaticulatum and V. calycinium. Pacific Science. 1974;48:458-63.

16. Arya SP, Mahajan M, Jain P. Non-spectrophotometric method for the determination of vitamin C. Analytical Chimica Acta. 2000;417(1):1-4.

17. Ndebia EJ, Kamga R, Nchunga-Anye NB. Analgesic and anti-inflammatory properties of aqueous extract from leaves of Solanum torvum (Solanaceae). African Journal of Traditional, Complementary, and Alternative Medicines. 2007;4(2):240-4

18. Boonkerd T, Songkhla BN, Thephuttee W. Solanum torvum Swartz. Bogor, Indonesia. 1994;258-60.

19. Sivapriya M, Srinivas L. Isolation and purification of a novel antioxidant protein from the water extract of Sundakai (Solanum torvum) seeds. Food Chemistry. 2007;104(2):510-7.

20. Lakshmi D, Prasanna N, Ponmurugan P. In vitro interactions between Solanum torvum extracts and microbes. Academic Journal of Cancer Research. 2013 6(2):74-8.

21. Mustafa RA, Abdul Hamid A, Mohamed S, Bakar FA. Total phenolic compounds, flavonoids, and radical scavenging activity of 21 selected tropical plants. Journal of Food Science. 2010;75(1):C28-35.

22. Ghasemzadeh A, Jaafar $H Z$, Rahmat A. Antioxidant activities, total phenolics and flavonoids content in two varieties of Malaysia young ginger (Zingiber officinale Roscoe). Molecules (Basel, Switzerland). 2010;15(6):4324-33.

23. Kalita S, Kumar G, Karthik L, Rao KV. In vitro antioxidant and DNA damage inhibition activity of aqueous extract of Lantana camaraL. (Verbenaceae) leaves. Asian Pac J Trop Biomed 2012;2(3):S1675-9.
24. Davis DR, Riordan HD. Changes in USDA food composition data for 43 garden crops. J Am Coll Nutr. 2004;23(6):669-82.

25. Nijveldt RJ, Nood VE, Hoorn DE, Boelens PG, Norren K, Leeuwen PA. Flavonoids: a review of probable mechanisms of action and potential applications. Am J Clin Nutr. 2001:74(4):418-25.

26. Vaclavikova R, Kondrova E, Ehrlichova DM, Boumendjel A, Kovar J, Stopka P.The effect of flavonoid derivatives on doxorubicin transport and metabolism. Bioorg Med Chem. 2008;16(4):2034-42.

27. Hertog MG, Feskens EJ, Hollman PC, Katan MB, Kromhout D. Dietary antioxidant flavonoids and Risk of coronary heart disease: the Zutphen Elderly Study. Lancet. 1993;342(8878):10-11.

28. Sies H, Stahl W. Vitamins E and C, beta-carotene and other carotenoids as antioxidants. American Journal of Clinical Nutrition. 1995;62(6):315-21.

29. Levine M. New concepts in the biology and biochemistry of ascorbic acid New England Journal of Medicine. 1986;314(14):892-902.

30. Levine M, Dhariwal KR, Welch RW, Wang Y, Park JB. Determination of optimal vitamin C requirements in humans. Am J Clin Nutr. 1995;62(6):1347S-56S

31. Fitriansyah SN, Aulifa DL, Febriani Y, Sapitri E. Correlation of Total Phenolic, Flavonoid and Carotenoid Content of Phyllanthus emblica Extract from Bandung with DPPH Scavenging Activties. Pharmacog J. 2018;10(3):447-52.

32. Nagy S, Smoot JM. Temperature and storage effects on percent retention and percent U.S. recommended dietary allowance of vitamin C in canned singlestrength orange juice." J Agric Food Chem. 1977;25(1):135-8.

33. Rath M. Eradicating Heart Disease. Health Now, San Francisco, California, U.S.A. 1993;42-6.

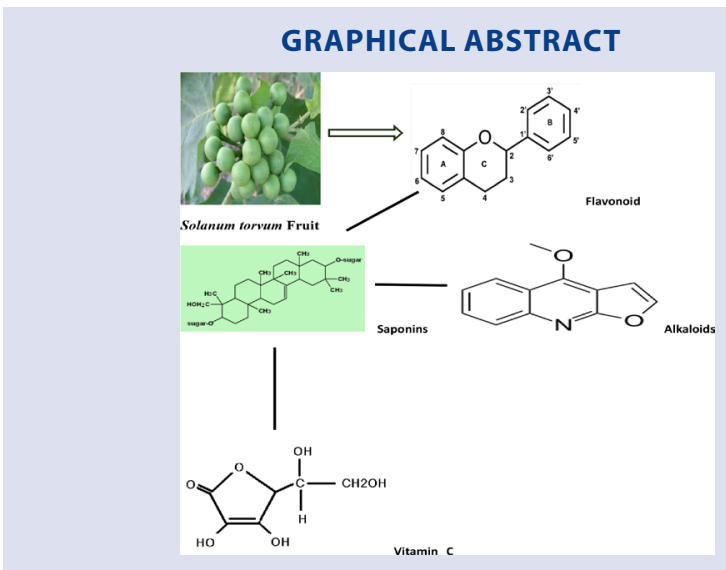

\section{SUMMARY}

- The study report the quantification of phytochemical constituents and vitamin C contents from ethanol extracts of Solanum torvum fruits.

- The main objective for this research was to use standard procedures to determine phytochemical and vitamin C content.

- The estimated alkaloids found in mature fruits were $6.32 \pm 0.12 \mathrm{mg} / \mathrm{g}$ and $16.94 \pm 2.3 \mathrm{mg} / \mathrm{g}$ in the immature fruits. Total saponins in mature and immature fruits were $8.60 \pm 2.6 \mathrm{mg} / \mathrm{g}$ and $16.90 \pm 9.4 \mathrm{mg} / \mathrm{g}$ respectively. Total flavonoids in mature and immature fruits were $21.14 \pm 4.4 \mathrm{mg} / \mathrm{g}$ and $14.24 \pm 1.8$ $\mathrm{mg} / \mathrm{g}$ respectively. Also vitamin C contents were $11.79 \pm 2.0 \mathrm{mg} / \mathrm{g}$ in mature fruits and $8.70 \pm 0.26 \mathrm{mg} / \mathrm{g}$ in immature fruits.

- The study showed that the extracts contain diversity of phytochemicals in appreciable amount that can expertly keep the body against oxidative stress triggered by free radicals and therefore be used as a source of potent natural products

\section{ABOUT AUTHORS}

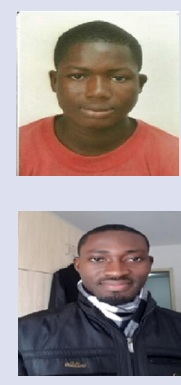

Bismark Odum: Is a Chemical Engineer and Management Consultant. He obtained his B.Sc. qualification in Chemical Engineering from Kwame Nkrumah University of Science and Technology, Kumasi-Ghana in June 2015. He obtained his professional diploma in Professional Consulting from Chartered Management Institute, United Kingdom (UK) in March 2018. He is currently a postgraduate student in Hohai University, Nanjing, China. His current research interest is in flocculation processes of cohesive sediment and its impact on water quality.

Benjamin Danso Kwakye: Is a Ghanaian with Bachelor's degree in Mathematics from Valley View University, Ghana in July 2016 after obtaining his Diploma in Basic Education (Science) in September 2011 at Wesley College of Education (University of Cape Coast), Ghana. He is currently an M.Sc candidate in Mathematics with research interest in Statistics and Statistical Analysis at Hohai University, Nanjing, China.

Cite this article: Koomson DA, Kwakye BD, Darkwah WK, Odum B, Asamoah KA. Phytochemical Constituents, Total Saponins, Alkaloids, Flavonoids and Vitamin C Contents of Ethanol Extracts of five Solanum torvum Fruits. Pharmacog J. 2018;10(5):946-50. 